\title{
Phenylalanine Kinetics in Human Adipose Tissue
}

\author{
S.W. Coppack, ${ }^{\star}$ M. Persson, and J.M. Miles \\ Endocrine Research Unit, Mayo Clinic, Rochester, Minnesota 55905; and *UCL Medical School, Whittington Hospital, London N19 \\ $3 U A$, United Kingdom
}

\begin{abstract}
Very little is known about the regulation of protein metabolism in adipose tissue. In this study systemic, adipose tissue, and forearm phenylalanine kinetics were determined in healthy postabsorptive volunteers before and during a 2-h glucose infusion $\left(7 \mathrm{mg} \cdot \mathrm{kg}^{-1} \cdot \mathrm{min}^{-1}\right) \cdot\left[{ }^{3} \mathrm{H}\right] \mathrm{Phenylalanine}$ was infused and blood was sampled from a radial artery, a subcutaneous abdominal vein, and a deep forearm vein. Adipose tissue and forearm blood flow were measured with ${ }^{133} \mathrm{Xe}$ and plethysmography, respectively, and body fat mass was determined by dual energy x-ray absorptiometry. During glucose infusion, glucose concentration increased from $86 \pm 2$ to $228 \pm 13 \mathrm{mg} / \mathrm{dl}$ and insulin concentration increased from $6.6 \pm 0.6$ to $35.0 \pm 3.9 \mathrm{mU} / \mathrm{liter}$, both $P<0.001$. Systemic phenylalanine appearance decreased from $40.3 \pm 1.9$ to $37.0 \pm 1.6 \mu \mathrm{mol} / \mathrm{min}$ during glucose infusion $(P<0.05)$. Baseline whole body adipose tissue phenylalanine release $(5.2 \pm 1.4 \mu \mathrm{mol} / \mathrm{min})$ was $\sim 12 \%$ of systemic phenylalanine appearance and decreased $(P<0.05)$ to $2.3 \pm 0.9 \mu \mathrm{mol} / \mathrm{min}$ during glucose infusion. In contrast, phenylalanine release from the forearm did not change during glucose infusion. These results indicate that adipose tissue is a small but significant contributor to systemic phenylalanine appearance. Phenylalanine release from adipose tissue, like lipolysis, is relatively sensitive to hyperinsulinemia. (J. Clin. Invest. 1996. 98:692-697.) Key words: amino acid • protein • tracer - insulin • forearm
\end{abstract}

\section{Introduction}

In vivo protein turnover is often measured with stable or radioactive tracers of leucine $(1,2)$, lysine (3), and phenylalanine (4). These methods allow a noninvasive assessment of protein synthesis and breakdown (3) and have been widely used to characterize the regulation of protein metabolism in normal, diabetic, stressed, and obese subjects (5-7) by insulin (8), gluco-corticoids (9), catecholamines (10), and growth hormone (11).

When an amino acid tracer is used in combination with the arteriovenous balance technique, it is possible to partition uptake (an indicator of protein synthesis) from release (an indicator of protein breakdown). Using a phenylalanine tracer, Barrett and colleagues have applied this technique (12) to the study of amino acid metabolism in skeletal muscle (13) and myocardium (14). Phenylalanine is particularly useful because

Address correspondence to John M. Miles, M.D., Diabetes Research Laboratory, St. Luke's Hospital, 44th \& Wornall Road, Kansas City, MO 64111. Phone: 816-932-6847; FAX: 816-932-6292.

Received for publication 6 December 1993 and accepted in revised form 8 April 1996.

The Journal of Clinical Investigation

Volume 98, Number 3, August, 1996, 692-697 it is not broken down in extrahepatic tissues (13). Thus, phenylalanine disappearance has been used as an index of protein synthesis in these tissues. Although skeletal muscle is by far the largest depot of body protein, it appears that, in relative terms, the splanchnic bed is a more active site of amino acid turnover (15).

Although protein turnover occurs in all tissues, the relative contribution of tissues such as brain, kidney, and adipose tissue to whole body protein economy and the dynamics of the regulation of protein metabolism in those tissues are not known. Physiological hyperinsulinemia has been shown to suppress systemic protein breakdown (8). The site(s) of this effect of hyperinsulinemia on proteolysis is (are) not known, but likely include(s) tissues other than skeletal muscle (16). In this study we have combined arteriovenous sampling across forearm and adipose tissue with infusion of a phenylalanine tracer to determine the relative contribution of adipose tissue to systemic phenylalanine turnover and the response of adipose tissue and forearm phenylalanine kinetics to glucose infusion in healthy human volunteers.

\section{Methods}

Subjects. 11 normal male volunteers were studied after obtaining written, informed consent. All volunteers were healthy nonsmokers and were taking no medications. Chemistry screen, hematology screen, and urinalysis were normal in each subject.

The subjects were admitted to the Mayo General Clinical Research Center at 1700 and on arrival ate a standard meal containing $20 \mathrm{kcal} \cdot \mathrm{kg}$ lean body mass $(\mathrm{LBM})^{-1}$ with $50 \%$ of calories as carbohydrate, $30 \%$ as fat, and $20 \%$ as protein. Thereafter the subjects consumed only clear caffeine- and calorie-free liquids. Body fat mass was determined by dual energy x-ray absorptiometry (Lunar Instruments, Madison, WI) (17). The characteristics of the subjects are shown in Table I.

Protocol. The protocol is depicted in Fig. 1. At 0700 the subjects were awakened, and blood sampling cannulae were inserted (using local anesthesia) into a radial artery, a superficial abdominal vein (18), and a contralateral deep forearm vein (19-24). An infusion cannula was placed in a forearm vein ipsilateral to the arterial cannula, and all cannulae were kept patent with controlled infusions of $0.9 \%$ $\mathrm{NaCl}$. In brief, the superficial abdominal vein was sampled from a cannula whose tip was just inferior to the inguinal ligament (by surface anatomy) $(18,25)$. A deep forearm (antecubital, usually the median cubital) vein was cannulated (19-23, 26-28) and samples were taken after exclusion of the hand circulation for $2-3 \mathrm{~min}$ by a sphygmomanometer cuff inflated to $60-100 \mathrm{mmHg}$ above arterial pressure. In two subjects, no anatomically suitable antecubital vein could be cannulated. The antecubital catheter was repositioned if necessary to achieve oxygen saturation $<60 \%$, and the samples were not analyzed if this was not accomplished (28).

After the cannulae were in place, a primed $(25 \mu \mathrm{Ci})$ constant infusion of L-[ring $2,6-{ }^{3} \mathrm{H}$ ]phenylalanine $\left(0.5 \mu \mathrm{Ci} \cdot \mathrm{min}^{-1}\right)$ was started (time $-150 \mathrm{~min}$ ) and continued for $270 \mathrm{~min}$. At time $-90 \mathrm{~min} 150$ $\mu \mathrm{Ci}$ of ${ }^{133} \mathrm{Xe}$ in $0.5 \mathrm{ml}$ sterile saline was injected into the subcutaneous abdominal adipose tissue in the drainage of the abdominal vein being sampled to estimate adipose tissue blood flow (29-32). The rate of washout of the depot of lipophilic xenon was monitored by an exter- 
Table I. Subject Characteristics

\begin{tabular}{cccccc}
\hline $\begin{array}{c}\text { Age } \\
(\mathrm{yr})\end{array}$ & $\begin{array}{c}\text { Height } \\
(\mathrm{m})\end{array}$ & $\begin{array}{c}\text { Weight } \\
(\mathrm{kg})\end{array}$ & $\begin{array}{c}\mathrm{BMI} \\
\mathrm{kg} \cdot \mathrm{m}^{-2}\end{array}$ & $\%$ Fat & $\begin{array}{c}\text { Fat mass } \\
(\mathrm{kg})\end{array}$ \\
\hline $26.8 \pm 1.3$ & $1.8 \pm 0.03$ & $74.6 \pm 2.1$ & $23.4 \pm 0.5$ & $16.4 \pm 0.9$ & $12.4 \pm 0.9$ \\
\hline
\end{tabular}

nal NaI detector, maintaining counting geometry, and after allowing a period of $60 \mathrm{~min}$ to permit resolution of any hyperemia associated with depot insertion. The rate of washout depends upon blood flow around the depot and the relative solubility of xenon in blood and adipose tissue.

At time 0 a 2-h infusion of $50 \%$ glucose was infused at 7 $\mathrm{mg} \cdot \mathrm{min}^{-1} \cdot \mathrm{kg}$ body weight ${ }^{-1}$. Blood samples were obtained from all three sampling cannulae at $-30,-20,-10$, and $0 \mathrm{~min}$ and again at 90 , 100, 110, and $120 \mathrm{~min}$.

Analyses. Adipose tissue blood flow was estimated from the decay of ${ }^{133} \mathrm{Xe}$ radioactivity, assuming a monoexponential decay and partition coefficient of 8.2 for adipose tissue/blood (33). Forearm blood flow was measured using a mercury strain gauge plethysmograph (34). Both forearm and adipose tissue blood flows were measured between -30 and $0 \mathrm{~min}$ and again between 90 and $120 \mathrm{~min}$.

Blood samples were taken and immediately transferred to precooled tubes containing EDTA and kept on ice until centrifuged at $4^{\circ} \mathrm{C}$, which was done within $30 \mathrm{~min}$ of the sample being drawn. Plasma was then stored at $-70^{\circ} \mathrm{C}$.

Plasma phenylalanine concentration and specific activity were measured by a modification of the HPLC method of LeCavalier et al. (35). The molarity of the sodium phosphate mobile phase was reduced from 0.2 to $0.05 \mathrm{M}$ and the flow rate was reduced from 1.4 to $1.0 \mathrm{ml} / \mathrm{min}$. Measurements were made on $1.0-\mathrm{ml}$ (instead of $2.0 \mathrm{ml}$ ) aliquots of plasma, and methylene chloride extracts were backextracted into $0.05 \mathrm{M}$ (instead of $0.2 \mathrm{M}$ ) $\mathrm{Na}_{2} \mathrm{PO}_{4}$ ( $\mathrm{pH} 7.0$ ).

Glucose concentration was determined using a Beckman Glucose Analyzer 2 (Beckman Instruments, Carlsbad, CA). Plasma insulin concentration was determined by radioimmunoassay (36).

Calculations and statistics. The following steady state formulae were used to calculate systemic and regional phenylalanine kinetics:

Systemic appearance $\left(R_{\mathrm{a}}\right)=\frac{\left[{ }^{3} H\right] \text { phenylalanine infusion rate }}{S A_{\mathrm{a}}}$
Fractional extraction $(F E)=\frac{[P h e]_{\mathrm{a}} \cdot S A_{\mathrm{a}}-[P h e]_{\mathrm{v}} \cdot S A_{\mathrm{v}}}{[P h e]_{\mathrm{a}} \cdot S A_{v}}$
Uptake $=F E \cdot[P h e]_{\mathrm{a}} \cdot P F$

\section{${ }^{3} \mathrm{H}$-phenylalanine}

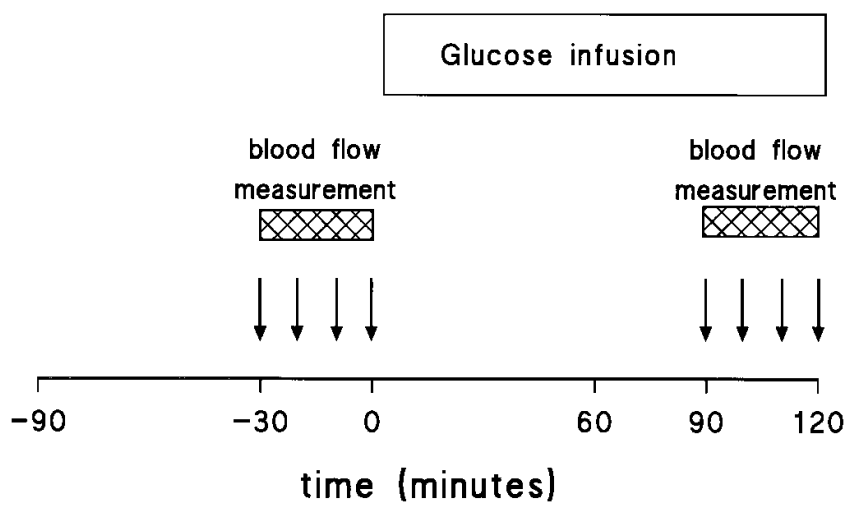

Figure 1. Study protocol. The arrows indicate blood sampling.

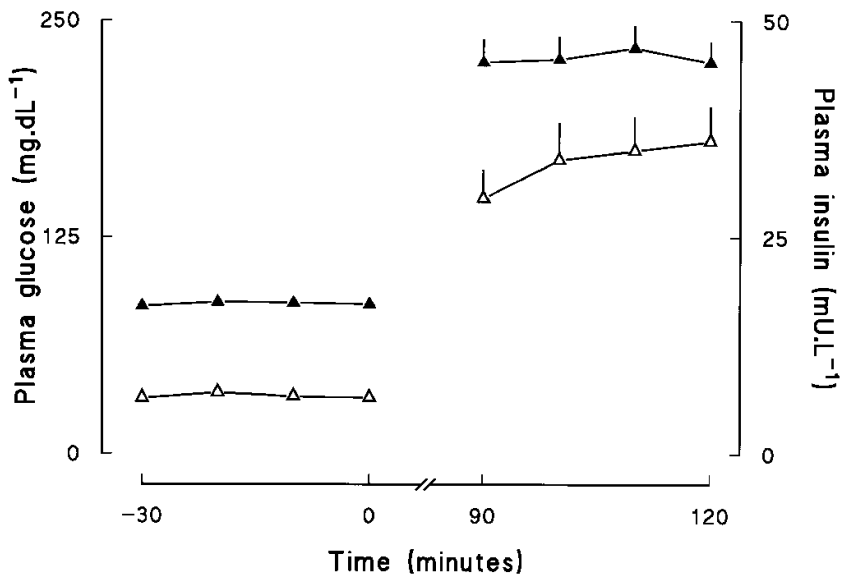

Figure 2. Arterial plasma glucose (closed triangles) and insulin (open triangles) concentrations before and during glucose infusion.

Release $=$ Uptake $+\left([\text { Phe }]_{\mathrm{v}}-[\text { Phe }]_{\mathrm{a}}\right) \cdot P F$

Net balance $=$ Uptake - Release

where $[P h e]$ is plasma phenylalanine concentration; $S A$ is plasma phenylalanine specific activity; $a$ is arterial; $v$ is venous; and $P F$ is plasma flow. These formulae are essentially identical to those used by Gelfand and Barrett (13). Mean values for concentration and specific
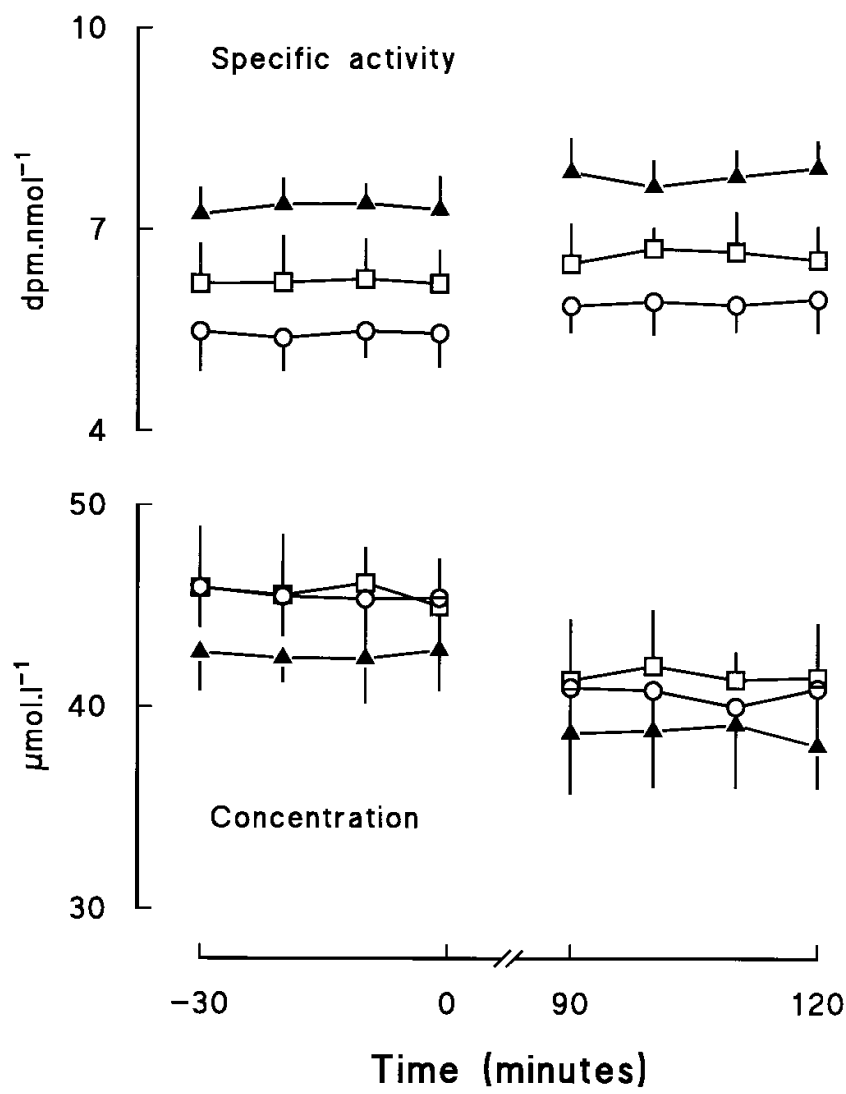

Figure 3. Phenylalanine specific activity (top) and concentration (bottom) in arterial (closed triangles), forearm venous (open circles), and abdominal venous (open squares) plasma. 
Table II. Steady-State Plasma Phenylalanine Concentration, Specific Activity, Fractional Extraction, and A-V Concentration Difference

\begin{tabular}{lccc}
\hline & Baseline & Glucose infusion & Significance \\
\hline Concentration ( $\mu$ mol/liter) & & & \\
$\quad$ Artery & $42.6 \pm 2.5$ & $38.8 \pm 1.9$ & $<0.01$ \\
Deep vein & $45.4 \pm 2.2$ & $40.6 \pm 2.0$ & $<0.05$ \\
Abdominal vein & $45.7 \pm 3.2$ & $41.7 \pm 2.6$ & $<0.05$ \\
$P$ (Artery vs. deep vein) & $<0.01$ & NS & \\
$P$ (Artery vs. abdominal vein) & $<0.05$ & $<0.05$ & \\
Specific activity (dpm/nmol) & & & \\
Artery & $7.3 \pm 0.3$ & $7.7 \pm 0.4$ & $<0.05$ \\
Deep vein & $5.5 \pm 0.3$ & $5.9 \pm 0.7$ & $<0.05$ \\
Abdominal vein & $6.2 \pm 0.4$ & $6.5 \pm 0.4$ & $<0.05$ \\
$P$ (Artery vs. deep vein) & $<0.01$ & $<0.01$ & \\
$P$ (Artery vs. abdominal vein) & $<0.01$ & $<0.01$ & \\
& & & \\
Fractional extraction (\%) & & & \\
Forearm & $* 17.0 \pm 1.8$ & $* 21.4 \pm 1.3$ & NS \\
Adipose tissue & $* 13.2 \pm 4.2$ & $* 9.2 \pm 3.4$ & NS \\
A-V difference ( $\mu$ mol/liter) & & & \\
Forearm & $* 3.6 \pm 0.7$ & $2.6 \pm 1.0$ & NS \\
Adipose tissue & $* 2.7 \pm 0.9$ & $* 2.8 \pm 1.0$ & NS \\
& & & \\
\hline
\end{tabular}

*Significantly different from zero.

activity during the baseline and 90-120-min sampling intervals were determined for each subject and used in the calculations. Means and medians showed similar trends: results are provided as mean \pm SEM. Statistical comparisons were performed by Wilcoxon's paired test.

\section{Results}

Near steady state conditions were achieved for both arterial glucose and insulin concentrations (Fig. 2). Plasma glucose increased from $86 \pm 2$ to $228 \pm 13 \mathrm{mg} / \mathrm{dl}(P<0.001)$ and plasma insulin increased from $6.6 \pm 0.6$ to $35.0 \pm 3.9 \mathrm{mU} /$ liter $(P<$ $0.001)$ during glucose infusion.

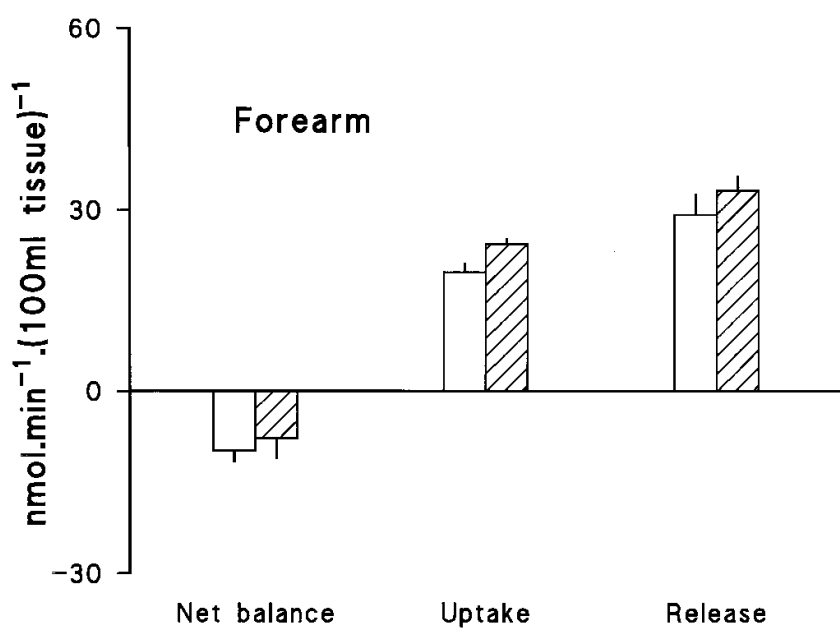

Figure 4. Net balance, uptake, and release of phenylalanine in the forearm before (open bars) and during (hatched bars) glucose infusion.

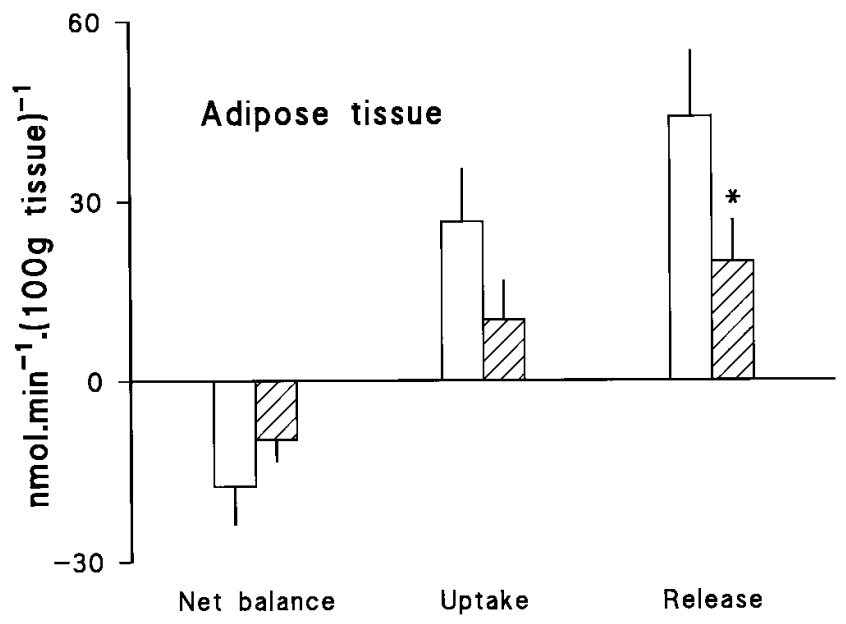

Figure 5. Net balance, uptake, and release of phenylalanine in adipose tissue before (open bars) and during (hatched bars) glucose infusion. $* P<0.05$.

Adipose tissue blood flow decreased significantly $(P<$ $0.05)$ from $5.5 \pm 0.9$ to $4.2 \pm 0.8 \mathrm{ml} \cdot \mathrm{min}^{-1} \cdot 100$ grams of tissue $^{-1}$ during the glucose infusion. Forearm blood flow did not change significantly during glucose infusion (baseline 2.7 \pm 0.7 , glucose infusion $3.0 \pm 0.7 \mathrm{ml} \cdot \mathrm{min}^{-1} \cdot 100 \mathrm{ml}^{-1}$ forearm, $P=\mathrm{NS}$ ).

Phenylalanine concentration and specific activity are shown in Fig. 3. Mean values for concentration, specific activity, fractional extraction, and arteriovenous concentration difference for the two sampling intervals are provided in Table II. All fractional extraction data are significantly different from zero $(P<0.05)$; the significance of the arteriovenous difference data versus zero is shown in the comparisons of arterial versus venous concentrations at the top of the table. Figs. 4 and 5 show phenylalanine net balance, uptake, and release across the forearm and adipose tissue beds, respectively. As can be seen, net balance of phenylalanine was negative in both the forearm and adipose tissue before and during glucose infusion. Phenylalanine uptake in the forearm did not change during glucose infusion. There was also no change in phenylalanine release in the forearm during glucose infusion. However, phenylalanine release decreased in adipose tissue from $44.1 \pm 11.4$ to $19.9 \pm 7.5 \mathrm{nmol} \cdot 100$ grams of tissue ${ }^{-1} \cdot \mathrm{min}^{-1}(P<0.05)$. Phenylalanine uptake in adipose tissue decreased from $26.6 \pm 8.9$ to $10.1 \pm 6.6 \mathrm{nmol} \cdot 100$ grams of tissue ${ }^{-1} \cdot \mathrm{min}^{-1}$, but the decrease was not statistically significant $(P=0.08)$.

Table III depicts systemic phenylalanine turnover together with estimates of whole body adipose tissue phenylalanine uptake and release, before and during glucose infusion. During

Table III. Systemic Phenylalanine Appearance $\left(R_{a}\right)$ and Whole Body Adipose Tissue Phenylalanine Release

\begin{tabular}{lcc}
\hline & Baseline & Glucose infusion \\
\hline $\begin{array}{l}\text { Phenylalanine } \mathrm{R}_{\mathrm{a}}(\mu \mathrm{mol} / \mathrm{min}) \\
\begin{array}{c}\text { Adipose tissue } \mathrm{phenylalanine} \\
\text { release }(\mu \mathrm{mol} / \mathrm{min})\end{array}\end{array}$ & $40.3 \pm 1.9$ & $* 37.0 \pm 1.6$ \\
& $5.2 \pm 1.4$ & $* 2.3 \pm 0.9$
\end{tabular}

$* P<0.05$ vs. baseline. 
the baseline period, adipose tissue phenylalanine release was $\sim 12 \%$ of systemic $R_{\mathrm{a}}$, declining to $\sim 6 \%$ during glucose infusion. Systemic phenylalanine $R_{\mathrm{a}}$ decreased $(P<0.05)$ during glucose infusion.

\section{Discussion}

These studies demonstrate that simultaneous uptake and release of the essential amino acid phenylalanine occurs in abdominal adipose tissue of normal postabsorptive human subjects. To our knowledge, this is the first demonstration of evidence of phenylalanine uptake and release in adipose tissue in vivo and allows an estimate of the contribution of adipose tissue to whole body amino acid metabolism. Using the data on phenylalanine release from abdominal adipose tissue together with body fat mass determined by dual energy $\mathrm{x}$-ray absorptiometry, it is possible to estimate phenylalanine kinetics in total body fat. This extrapolation suggests that $\sim 12 \%$ of phenylalanine $R_{\mathrm{a}}$ is derived from adipose tissue. While this is a relatively small fraction of total $R_{\mathrm{a}}$, it is considerably greater than the apparent contribution of the myocardium to systemic phenylalanine appearance (14). Caution is warranted in regard to such extrapolation, however, since the metabolic heterogeneity of human adipose tissue is well documented with differences in blood flow, lipolytic activity, and response to hormonal stimuli among the various adipose tissue depots (37-39).

Phenylalanine $R_{\mathrm{a}}$ decreased significantly $(P<0.05)$ during glucose infusion, although the decrease was modest $(\sim 9 \%)$. Whereas it is possible that hyperglycemia could have been the cause of this change via a direct effect of glucose on phenylalanine metabolism, it seems more likely that the hyperinsulinemia resulting from glucose infusion was the mediator of changes in phenylalanine kinetics, both systemically and in adipose tissue. Other investigators have reported decreases of $20-40 \%$ in leucine (40) or phenylalanine (16) $R_{\mathrm{a}}$ in response to systemic hyperinsulinemia. In these studies, insulin was infused at rates producing plasma insulin concentrations significantly higher (16, 40) than those observed during glucose infusion in the present study; when insulin was infused at a much lower rate in normal subjects, a decrease in leucine $R_{\mathrm{a}}$ occurred comparable with that observed in the present study $(7,8)$. Furthermore, the decrease in amino acid $R_{\mathrm{a}}$ in some of the earlier studies $(16,40)$ was demonstrated after a longer duration of hyperinsulinemia. It should be recognized that a longer interval between the two sampling periods can in part account for lower rates of apparent phenylalanine $R_{\mathrm{a}}$ because of progressive recycling of tracer, as has been documented with constant infusions of leucine (41).

The dramatic (almost $60 \%$ ) decrease in release of phenylalanine from adipose tissue observed in this study stands in contrast to the lack of effect of glucose infusion on forearm phenylalanine kinetics and could account for the majority of the decrease in systemic phenylalanine $R_{\mathrm{a}}$ if matched by similar changes in other adipose tissue depots. An elegant study by Gelfand and Barrett found that local hyperinsulinemia $(>120$ $\mu \mathrm{U} / \mathrm{ml}$ ) induced by direct infusion of insulin into the brachial artery resulted in an $\sim 40 \%$ suppression of phenylalanine release from the forearm of normal volunteers (13). In contrast, Tessari et al. found a decrease in systemic phenylalanine $R_{\mathrm{a}}$ but not forearm phenylalanine release during a systemic euglycemic insulin clamp producing plasma insulin concentrations of $\sim 75 \mu \mathrm{U} / \mathrm{ml}$ (16). In that study, forearm phenylalanine release actually decreased by $>20 \%$, but the change was not sig- nificant. The discrepancy between the findings of Tessari et al. and those of Gelfand and Barrett may relate to differences between localized (13) and systemic (16) hyperinsulinemia, since a significant decrease in arterial plasma phenylalanine concentrations occurs in the latter, but not the former situation. Alternatively, the failure of Tessari et al. to demonstrate a significant decrease in forearm phenylalanine release (16) could be due to a type II statistical error. In this study, forearm phenylalanine release did not change. Although our subjects had a lesser degree of hyperinsulinemia compared with previous studies ( 35 vs. $75-125 \mu \mathrm{U} / \mathrm{ml}$, references 13 and 16), the failure to suppress forearm phenylalanine release may relate to the concurrent presence of hyperglycemia, which can independently stimulate proteolysis (42). This interpretation is supported by the observation that direct intraarterial insulin infusion producing increases in insulin concentration of only 20 $\mu \mathrm{U} / \mathrm{ml}$ results in a significant antiproteolytic effect in the forearm of normal postabsorptive subjects (43).

The decrease in phenylalanine release from adipose tissue in response to glucose infusion may have been due in part to a decrease in adipose tissue blood flow. There were also nonsignificant decreases in fractional extraction of phenylalanine and in the arteriovenous concentration differences in adipose tissue; these changes also contributed to the significant decrease in phenylalanine release. This decrease in blood flow is similar to the response to intravenous insulin (31) and contrasts with the increase in blood flow observed after a mixed meal (29).

We found that the net balance of phenylalanine was negative in both forearm and adipose tissue, even during hyperinsulinemia induced by glucose infusion. Similar results have been reported by others in both forearm (13) and myocardium (14) but should not be taken to necessarily indicate net protein catabolism, since a significant amount of precursor amino acid for protein synthesis can derive from large molecular weight proteins such as albumin which are taken up from arterial plasma by a variety of tissues and degraded (15).

The combination of tracer infusion and the arteriovenous balance technique is particularly powerful in that it permits partitioning of uptake and release. This approach has been used successfully in the measurement of the regional metabolism of free fatty acid acids (44) and acetate (45) as well as phenylalanine (13). Although the present study is the first application of this approach in adipose tissue, there have been several reports of successful measurement of arteriovenous concentration differences in adipose tissue using cannulation of the superficial epigastric vein (46). This vein represents a nearly pure venous effluent from abdominal adipose tissue with little apparent contamination from underlying fascia and muscle (47, 48). Although adipose tissue blood flow is relatively brisk with resulting small arteriovenous differences in a variety of substrates, we demonstrated significant differences between arterial and abdominal venous phenylalanine concentration and specific activity in this study, in part because of the excellent precision (coefficient of variation $<3 \%$ ) of the HPLC method used for the measurements. The use of tracers in this study, as in any study using isotope dilution, generates minimal estimates of both whole body and regional kinetics because of tracer disequilibrium resulting in lower specific activities within intracellular pools (49). Thus, the rates of release found in the present study are inevitably lower than actual rates of proteolysis.

The discrepancy between the antiproteolytic effect of glucose infusion in adipose tissue and in the forearm is not en- 
tirely surprising. It seems likely that the significant effects of glucose infusion were mediated by insulin, especially since hyperglycemia per se appears to increase proteolysis in the absence of insulin (42). The degree of hyperinsulinemia achieved in our study was modest. Adipose tissue is known to be more sensitive to the antilipolytic effects of insulin than are muscle and liver with respect to the effects of insulin on glucose metabolism (50); significant suppression of hormone-sensitive lipase in adipose tissue occurs with changes in insulin concentration of $<2 \mu \mathrm{U} / \mathrm{ml}$ (51). The concentration threshold for the antiproteolytic effects of insulin in various tissues is not known and will require further study.

In summary, our results demonstrate active uptake and release of phenylalanine in human adipose tissue. Since phenylBalanine is not oxidized in extrahepatic tissues (4), its uptake in adipose tissue likely reflects protein synthesis. Similarly, since phenylalanine cannot be synthesized, its release from adipose tissue is a reflection of proteolysis. The marked suppression of phenylalanine release from adipose tissue which occurred during glucose infusion is likely mediated by moderate hyperinsulinemia.

\section{Acknowledgments}

We thank W. Schauer and E. Lim for technical support, A. Pelot for editorial help, Dr. R. A. Rizza for providing the insulin measurements, and the staff of the Mayo General Clinical Research Center for their excellent assistance.

This study was supported in part by grants from the U.S. Public Health Service (DK38092 and RR00585) and the Mayo Foundation. S.W. Coppack held a Fulbright Scholarship.

\section{References}

1. O'Keefe, S.J.D., and P.M. Sender. 1974. "Catabolic" loss of body nitrogen in response to surgery. Lancet. 2:1035-1038.

2. Matthews, D.E., K.J. Motil, D.K. Rohrbaugh, J.F. Burke, V.R. Young, and D.M. Bier. 1980. Measurement of leucine metabolism in man from a primed, continuous infusion of L-[1- $\left.{ }^{13} \mathrm{C}\right]$ leucine. Am. J. Physiol. 238:E473-E479.

3. Irving, C.S., M.R. Thomas, E.W. Malphus, L. Marks, W.W. Wong, T.W. Boutton, and P.D. Klein. 1986. Lysine and protein metabolism in young women. Subdivision based on the novel use of multiple stable isotopic labels. $J$. Clin. Invest. 77:1321-1331.

4. Clarke, J.T.R., and D.M. Bier. 1982. The conversion of phenylalanine to tyrosine in man. Direct measurement by continuous intravenous tracer infusions of $\mathrm{L}-\left(\right.$ ring $\left.{ }^{2} \mathrm{H}_{5}\right)$ phenylalanine and $\mathrm{L}\left(\mathrm{l}^{13} \mathrm{C}\right)$ tyrosine in the postabsorptive state. Metab. Clin. Exp. 31:999-1005.

5. Tessari, P., G. Pehling, S.L. Nissen, J.E. Gerich, F.J. Service, R.A. Rizza, and M.W. Haymond. 1988. Regulation of whole-body leucine metabolism with insulin during mixed-meal absorption in normal and diabetic humans. Diabetes. 37:512-519.

6. Wolfe, R.R., R.D. Goodenough, J.F. Burke, and M.H. Wolfe. 1983. Response of protein and urea kinetics in burn patients to different levels of protein intake. Ann. Surg. 197:163-171.

7. Jensen, M.D., and M.W. Haymond. 1991. Protein metabolism in obesity: effects of body fat distribution and hyperinsulinemia on leucine turnover. Am. J. Clin. Nutr. 53:172-176.

8. Tessari, P., R. Trevisan, S. Inchiostro, G. Biolo, R. Nosadini, S.V. De Kreutzenberg, E. Duner, A. Tiengo, and G. Crepaldi. 1986. Dose-response curves of effects on insulin on leucine kinetics in humans. Am. J. Physiol. 251: E334-E342.

9. Simmons, P.S., J.M. Miles, J.E. Gerich, and M.W. Haymond. 1984. Increased proteolysis. An effect of increases in plasma cortisol within the physiologic range. J. Clin. Invest. 73:412-420.

10. Miles, J.M., S.L. Nissen, J.E. Gerich, and M.W. Haymond. 1984. Effects of epinephrine infusion on leucine and alanine kinetics in humans. Am. J. Physiol. 247:E166-E172.

11. Horber, F.F., and M.W. Haymond. 1990. Human growth hormone prevents the protein catabolic side effects of prednisone in humans. J. Clin. Invest. $86: 265-272$.

12. Barrett, E.J., J.H. Revkin, L.H. Young, B.L. Zaret, R. Jacob, and R.A. Gelfand. 1987. An isotopic method for measurement of muscle protein synthe- sis and degradation in vivo. Biochem. J. 245:223-228.

13. Gelfand, R.A., and E.J. Barrett. 1987. Effect of physiologic hyperinsulinemia on skeletal muscle protein synthesis and breakdown in man. J. Clin. Invest. 80:1-6.

14. Young, L.H., P.H. McNulty, C. Morgan, L.I. Deckelbaum, B.L. Zaret, and E.J. Barrett. 1991. Myocardial protein turnover in patients with coronary artery disease. Effect of branched chain amino acid infusion. J. Clin. Invest. 87: 554-560.

15. De Feo, P., F.F. Horber, and M.W. Haymond. 1992. Meal stimulation of albumin synthesis: a significant contributor to whole body protein synthesis in humans. Am. J. Physiol. 263:E794-E799.

16. Tessari, P., S. Inchiostro, G. Biolo, E. Vincenti, L. Sabadin, and M. Vettore. 1991. Effects of acute systemic hyperinsulinemia on forearm muscle proteolysis in healthy man. J. Clin. Invest. 88:27-33.

17. Jensen, M.D., J.A. Kanaley, L.R. Roust, P.C. O'Brien, J.S. Braun, W.L. Dunn, and H.W. Wahner. 1993. Assessment of body composition with use of dual-energy X-ray absorptiometry: evaluation and comparison with other methods. Mayo Clin. Proc. 68:867-873.

18. Frayn, K.N., S.W. Coppack, S.M. Humphreys, and P.L. Whyte. 1989. Metabolic characteristics of human adipose tissue in vivo. Clin. Sci. 76:509-516.

19. Wahren, J. 1966. Quantitative aspects of blood flow and oxygen uptake in the human forearm during rhythmic exercise. Acta Physiol. Scand. Suppl. 67(Suppl. 269):5-93.

20. Andres, R., G. Cader, and K.L. Zierler. 1956. The quantitatively mino role of carbohydrate in oxidative metabolism by skeletal muscle in intact man in the basal state: measurements of oxygen and glucose uptake and carbon dioxide and lactate production in the forearm. J. Clin. Invest. 35:671-682.

21. Jackson, R.A., R.D. Roshania, M.I. Hawa, B.M. Sim, and L. DiSilvio. 1986. Impact of glucose ingestion on hepatic and peripheral glucose metabolism in man: an analysis based on simultaneous use of the forearm and double isotope techniques. J. Clin. Endocrinol. \& Metab. 63:541-549.

22. Rössner, S., B. Eklund, L. Kaijser, A.G. Olsson, and G. Walldius. 1976. Removal of exogenous plasma triglycerides in forearm muscle and subcutaneous tissue of hyper- and normotriglyceridaemic men. Eur. J. Clin. Invest. 6:299305 .

23. Mottram, R.F., and W.J.H. Butterfield. 1961. The human forearm as a preparation for metabolic investigations. Proc. R. Soc. Med. 54:549-552.

24. Kaijser, L., and S. Rössner. 1975. Removal of exogenous triglycerides in human forearm muscle and subcutaneous tissue. Acta Med. Scand. 197:289-294.

25. Coppack, S.W., R.D. Evans, R.M. Fisher, K.N. Frayn, G.F. Gibbons, S.M. Humphreys, M.J. Kirk, J.L. Potts, and T.D.R. Hockaday. 1992. Adipose tissue metabolism in obesity: lipase action in vivo before and after a mixed meal. Metab. Clin. Exp. 41:264-272.

26. Robertson, D.A., B.M. Singh, R.M. Baddeley, and M. Nattrass. 1990. Metabolic abnormalities in obese patients with impaired glucose tolerance. $\mathrm{Di}$ abetic Med. 7:45-49.

27. Coles, D.R., K.E. Cooper, R.F. Mottram, and J.V. Occleshaw. 1958. The source of blood samples withdrawn from deep forearm veins via catheters passed upstream from the median cubital vein. J. Physiol. 142:323-328.

28. Moller, N., P.C. Butler, M.A. Antsiferov, and K.G.M.M. Alberti. 1989 Effects of growth hormone on insulin sensitivity and forearm metabolism in normal man. Diabetologia. 32:105-110.

29. Coppack, S.W., R.M. Fisher, G.F. Gibbons, S.M. Humphreys, M.J. McDonough, J.L. Potts, and K.N. Frayn. 1990. Postprandial substrate deposition in human forearm and adipose tissues in vivo. Clin. Sci. 79:339-348.

30. Quaade, F., O.A. Larsen, N.A. Lassen, and S.L. Nielsen. 1967. Observations on the influence of glucose upon subcutaneous adipose tissue blood flow. Acta Med. Scand. Suppl. 476:85-90.

31. Prinz, W.A., D.B. West, A. Cohen, S. Silverberg, and M.R.C. Greenwood. 1986. Intraarterial insulin infusion reduces adipose tissue blood flow. Fed. Proc. 45:601a. (Abstr.)

32. Nielsen, S.L. 1972. Adipose tissue blood flow determined by the washout of locally injected ${ }^{133}$ Xenon. Scand. J. Clin. Lab. Invest. 29:31-36.

33. Bülow, J., R. Jelnes, A. Astrup, J. Madsen, and P. Vilmann. 1987. Tissue/blood partition coefficients for xenon in various adipose tissue depots in man. Scand. J. Clin. Lab. Invest. 47:1-3.

34. Cooper, K., O. Edholm, and R. Mottram. 1955. The blood flow in skin and muscle of the human forearm. J. Physiol. 128:258-267.

35. LeCavalier, L., F.F. Horber, and M.W. Haymond. 1989. Determination of plasma concentrations and ${ }^{3} \mathrm{H}$-specific activity of phenylalanine in plasma using high-performance liquid chromatography. J. Chromatogr. 491:410-417.

36. Herbert, V., K. Lau, C. Gottlieb, and S. Bleicher. 1965. Cooled charcoal immunoassay of insulin. J. Clin. Endocrinol. \& Metab. 25:1375-1384.

37. Binder, C., T. Lauritzen, O. Faber, and S. Pramming. 1984. Insulin pharmacokinetics. Diabetes Care. 7:188-199.

38. Wahrenberg, H., F. Lonnqvist, and P. Arner. 1989. Mechanisms underlying regional differences in lipolysis in human adipose tissue. J. Clin. Invest. 84: 458-467.

39. Peiris, A., R.A. Mueller, G.A. Smith, M.F. Struve, and A. Kissebah 1986. Splanchnic-insulin metabolism in obesity. Influence of body fat distribution. J. Clin. Invest. 78:1648-1657.

40. Castellino, P., L. Luzi, D.C. Simonson, M. Haymond, and R.A. De- 
Fronzo. 1987. Effect of insulin and plasma amino acid concentrations on leucine metabolism in man. J. Clin. Invest. 80:1784-1793.

41. Rodriguez, N., W.F. Schwenk, B. Beaufrere, J.M. Miles, and M.W. Haymond. 1986. Trioctanoin infusion increases in vivo leucine oxidation: a lesson in isotope modeling. Am. J. Physiol. 251:E343-E348.

42. Flakoll, P.J., J.O. Hill, and N.N. Abumrad. 1993. Acute hyperglycemia enhances proteolysis in normal man. Am. J. Physiol. 265:E715-E721.

43. Louard, R.J., D.A. Fryburg, R.A. Gelfand, and E.J. Barrett. 1992. Insulin sensitivity of protein and glucose metabolism in human forearm skeletal muscle. J. Clin. Invest. 90:2348-2354.

44. Dagenais, G.R., R.G. Tancredi, and K.L. Zierler. 1976. Free fatty acid oxidation by forearm muscle at rest, and evidence for an intramuscular lipid pool in the human forearm. J. Clin. Invest. 58:421-431.

45. Bleiberg, B., T.R. Beers, M. Persson, and J.M. Miles. 1992. Systemic and regional acetate kinetics in dogs. Am. J. Physiol. 262:E197-E202.
46. Coppack, S.W., M.D. Jensen, and J.M. Miles. 1994. The in vivo regulation of lipolysis in humans. J. Lipid Res. 35:177-193.

47. Frayn, K.N. 1992. Studies of human adipose tissue in vivo. In Energy Metabolism: Tissue Determinants and Cellular Corollaries. J.M. Kinney and H.N. Tucker, editors. Raven Press, Ltd., New York. 267-298.

48. Arner, P., and J. Bülow. 1993. Assessment of adipose tissue metabolism in man: comparison of Fick and microdialysis techniques. Clin. Sci. 85:247-256.

49. Horber, F.F., C.M. Horber-Feyder, S. Krayer, W.F. Schwenk, and M.W. Haymond. 1989. Plasma reciprocal pool specific activity predicts that of intracellular free leucine for protein synthesis. Am. J. Physiol. 257:E385-E399.

50. Nurjhan, N., P.J. Campbell, F.P. Kennedy, J.M. Miles, and J.E. Gerich. 1986. Insulin dose-response characteristics for suppression of glycerol release and conversion to glucose in humans. Diabetes. 35:1326-1331.

51. Jensen, M.D., M. Caruso, V.J. Heiling, and J.M. Miles. 1989. Insulin regulation of lipolysis in nondiabetic and IDDM subjects. Diabetes. 38:1595-1601. 